\title{
Pengaruh Penerapan Standar Akuntansi Pemerintah, Sistem Informasi Akuntansi, Sistem Pengendalian Intern, dan Kompetensi Sumber Daya Manusia Terhadap Kualitas Laporan Keuangan OPD di Kabupaten Labuhanbatu
}

\author{
Siti Hasanah ${ }^{1}$, Tapi Rumondang Sari Siregar ${ }^{2}$ \\ Universitas Negeri Medan ${ }^{1}$, Universitas Negeri Medan ${ }^{2}$ \\ siti.hasanah@wbi.ac.id ${ }^{1}$, tapi.rumondang@wbi.ac.id ${ }^{2}$
}

\begin{abstract}
Abstrak
Penelitian ini bertujuan menguji pengaruh standar akuntansi pemerintah, sistem informasi akuntansi, sistem pengendalian intern dan kompetensi sumber daya manusia terhadap kualitas laporan keuangan OPD di kabupaten Labuhanbatu. Variabel dependen dalam penelitian ini adalah kualitas laporan keuangan. Sedangkan variabel independennya adalah standar akuntansi pemerintah, sistem informasi akuntansi, sistem pengendalian intern dan kompetensi sumber daya manusia. Responden dalam penelitian ini adalah pejabat pengelola keuangan/kasubbag, bendahara dan staf pembantu penyusun laporan keuangan di seluruh OPD Labuhanbatu. Jumlah sampel dalam penelitian ini adalah 60 responden. Penelitian ini menggunakan sumber data primer dengan menyebarkan kuesioner di seluruh OPD Labuhanbatu. Teknik analisis data dalam penelitian ini menggunakan analisis regresi linier berganda yang digunakan untuk menguji hipotesis dalam penelitian ini.

Hasil penelitian ini memberikan bukti bahwa standar akuntansi pemerintah dan sistem informasi akuntansi memiliki pengaruh terhadap kualitas laporan keuangan. Sedangkan variabel sistem pengendalian intern dan kompetensi sumber daya manusia tidak memiliki pengaruh terhadap kualitas laporan keuangan. Jadi variabel yang berpengaruh dalam penelitian ini adalah standar akuntansi pemerintah dan sistem informasi akuntansi.
\end{abstract}

Kata Kunci : $\quad$ Standar akuntansi pemerintah, sistem informasi akuntansi, sistem pengendalian intern, kompetensi sumber daya manusia, kualitas laporan keuangan 


\section{Pendahuluan}

Peraturan pemerintah Nomor 8 tahun 2006, tentang laporan keuangan menyebutkan bahwa laporan keuangan adalah bentuk pertanggungjawaban pengelolaan keuangan negara/daerah selama satu periode. Dalam rangka menghasilkan laporan keuangan yang berkualitas, laporan keuangan harus memenuhi kriteria yang memadai yaitu memiliki relevansi, dapat diandalkan, dapat dinilai atau dibandingkan, dan dapat dipahami. Peraturan Pemerintah nomor 71 tahun 2010 menyebutkan bahwa laporan keuangan merupakan laporan terstruktur mengenai posisi keuangan dan transaksi-transaksi yang dilakukan oleh suatu entitas pelaporan. Laporan keuangan pemerintah daerah (LKPD) terdiri atas 7 (tujuh) komponen, yaitu: neraca, laporan operasional, laporan arus kas, laporan perubahan ekuitas, laporan realisasi anggaran, laporan perubahan saldo anggaran lebih dan catatan atas laporan keuangan (CaLK).

Demi meningkatkan kualitas transparansi dan akuntabilitas laporan keuangan pemerintah daerah, maka laporan keuangan tersebut perlu diperiksa oleh Badan Pemeriksa Keuangan (BPK). laporan Keuangan Pemerintah Daerah (LKPD) setiap tahunnya mendapat penilaian berupa opini dari Badan Pemeriksa Keuangan (BPK). Terdapat empat opini yang diberikan pemeriksa yaitu opini Wajar Tanpa Pengecualian (WTP), opini Wajar Dengan Pengecualian (WDP), opini Tidak Wajar (TW), dan Pernyataan Menolak memberi opini atau Tidak Memberi Pendapat (TMP).

Dari hasil pemeriksaan BPK sesuai dengan Ikhtisar Hasil Pemeriksaan Semester (IHPS) selama empat tahun terakhir dari tahun 2015-2018, BPK memberikan opini WDP kepada pemerintah Labuhanbatu setelah sebelumnya di tahun 2014 memperoleh opini WTP. Pada pemeriksaan atas 9 LKPD Tahun 2015 yang terlambat disampaikan dari 542 LKPD yang wajib disusun. BPK memberikan opini WTP atas 1 LKPD, opini WDP atas 7 LKPD dan opini TMP atas 1 LKPD. Empat (4) LKPD tidak mengalami perubahan opini dibanding tahun sebelumnya. Sedangkan 4 LKPD Tahun 2015 mengalami penurunan opini, yaitu dari WTP menjadi WDP pada 2 pemda di Provinsi Sumatera Utara, yaitu Pemkab Humbang Hasundutan dan Pemkab Labuhanbatu. Berdasarkan IHPS penurunan opini tersebut disebabkan karena ketidak sesuaian SAP dengan aset tetap, pendapatan dan beban-LO, kas, aset lancar selain kas, investasi, aset tetap, belanja modal, pendapatan-LO, dan akun lainnya.

Dalam IHPS II Tahun 2015 dijelaskan, hasil pemeriksaan atas seluruh Laporan Keuangan Pemerintah Daerah (LKPD) tahun 2014 (539 LKPD), BPK memberikan opini WTP atas 252 (47\%) LKPD, opini WDP atas 247 (46\%) LKPD, opini TMP atas 35 (6\%) LKPD, dan opini TW atas $5(1 \%)$ LKPD. Sementara itu, dalam IHPS Tahun 2016 dijelaskan hasil pemeriksaan atas seluruh Laporan keuangan Pemerintah Daerah (LKPD) tahun 2015 (533 LKPD), BPK memberikan opini WTP atas 312 (58\%) LKPD, opini WDP atas 187 (35\%) LKPD, opini TMP atas 30 (6\%) LKPD, dan opini TW atas 4 (1\%) LKPD. Secara keseluruhan, jumlah LKPD yang memperoleh opini WTP mengalami kenaikan dari 252 LKPD menjadi 312 LKPD atau naik sebesar $11 \%$.

Namun dalam IHPS tahun 2015 setelah dibandingkan dengan tahun 2016 jumlah pelaporan LKPD mengalami penurunan dari 539 LKPD menjadi 533 LKPD. Hal ini menjadi timpang dengan persentase opini yang diberikan oleh BPK dimana di jelaskan dalam IHPS, bahwa penilaian LKPD mengalami kenaikan sebesar $11 \%$ sementara pelaporan LKPD tersebut mengalami penurunan. Penurunan tersebut di sebabkan masih banyak pemerintahan daerah yang belum menyerahkan LKPD kepada BPK. Hal terebut salah satunya terjadi pada pemerintahan kabupaten Labuhanbatu.

Keterlambatan penyerahan LKPD oleh pemerintah kabupaten Labuhanbatu kepada BPK dan penurunan opini yang diperoleh menimbulkan tanda tanya atas menurunnya kualitas laporan keuangan yang diperoleh pemerintah Kabupaten Labuhanbatu. Dari fenomena tersebut dapat kita ketahui bahwa pemerintah kabupaten Labuhanbatu belum sepenuhnya melakukan prinsip akuntabilitas karena masih terjadi keterlambatan dalam melaporakan LKPD ke BPK.

Dalam pengelolaan keuangan, pemerintah melakukan reformasi dengan mengeluarkan UndangUndang Nomor 17 Tahun 2003 tentang Keuangan Negara yang mensyaratkan bentuk dan isi laporan pertanggungjawaban pelaksanaan Anggaran Pendapatan dan Belanja Negara (APBN) atau Anggaran Pendapatan dan Belanja Daerah (APBD) disusun dan disajikan dengan standar akuntansi pemerintahan yang ditetapkan oleh peraturan pemerintah. Pemerintah juga mengeluarkan Undang-Undang No. 32 Tahun 2004 tentang Pemerintahan Daerah. Berdasarkan Undang-Undang tersebut, pemerintah mengeluarkan Peraturan Pemerintah No. 24 Tahun 2005 tentang Standar Akuntansi Pemerintahan (SAP) serta Peraturan Pemerintah No.71 Tahun 2010 Tentang Standar Akuntansi Pemerintahan. 
Berdasarkan hal tersebut, penyusunan laporan keuangan harus bersandar pada SAP yang merupakan prinsip-prinsip akuntansi yang ditetapkan dalam menyusun dan menyajikan laporan keuangan pemerintah.

Pemerintah kabupaten Labuhanbatu pada Tahun Anggaran 2015 menerapkan kebijakan akuntansi berbasis akrual sesuai dengan Peraturan Pemerintah Nomor 71 Tahun 2010 tentang Standar Akuntansi Pemerintahan (SAP). Penerapan SAP harus sejalan dengan Sistem Informasi Akuntansi (SIA) yang digunakan dalam penyusunan laporan keuangan di suatu instansi pemerintahan. Maka salah satu hal yang mempengaruhi kualitas laporan keuangan adalah SIA. Sistem informasi akuntansi merupakan suatu komponen atau sub sistem dari suatu organisasi yang mempunyai tanggung jawab atas penyiapan informasi keuangan guna membantu manajemen dalam pembuatan keputusan (Irzal, 2017). Sistem informasi akuntansi dirancang untuk menghasilkan informasi berupa informasi keuangan yang dibutuhkan oleh pihak eksternal maupun internal lembaga/instansi. Sistem informasi akuntansi pada dasarnya dapat di operasikan tanpa menggunakan komputer, akan tetapi keterlibatan komputer dalam menangani tugas - tugas manusia dalam suatu sistem memiliki peran yang sangat besar dalam menunjang kelancaran sebuah sistem, sehingga informasi sangat dibutuhkan pihak manajemen dapat disajikan dengan cepat dan tepat waktu.

Selain kedua hal di atas yakni SAP dam SIA, hal lain yang dapat mempengaruhi kualitas LKPD adalah Sistem Pengendalian Intern (SPI). Menurut Peraturan Pemerintah No.60 Tahun 2008 pengertian Sistem Pengendalian Intern adalah sebagai berikut: "Sistem Pengendalian Intern adalah proses yang integral pada tindakan dan kegiatan yang dilakukan secara terus menerus oleh pimpinan dan seluruh pegawai untuk membe rikan keyakinan memadai atas tercapainya tujuan organisasi melalui kegiatan yang efektif dan efisien, keandalan pelaporan keuangan, pengamanan aset negara dan ketaatan terhadap peraturan perun dang-undangan."

Sedangkan pengertian Sistem Pengendalian Intern menurut Permendagri No. 4 Tahun 2008 Pedoman Pelaksanaan Reviu Atas Laporan Keuangan Daerah Pasal 1 (10) adalah: "Sistem pengendalian intern adalah suatu proses yang di pengaruhi oleh manajeman yang diciptakan untuk memberikan keyakinan yang memadai dalam penciptaan efektivitas, efisiensi, ketaatan terhadap peraturan perundang-undang an yang berlaku dan keandalan penyajian keuangan daerah."

Adanya penerapan kebijakan akuntansi berbasis akrual dalam laporan keuangan lebih berat dari tahun-tahun sebelumnya, sehingga diperlukan sumber daya manusia yang benar-benar memahami logika akuntansi. Maka Sumber Daya Manusia berpengaruh terhadap kualitas LKPD. Pemahaman Sumber Daya Manusia (SDM) yaitu khususnya pegawai bagian akuntansi, terkait konsep Akuntansi Berbasis Akrual akan mempengaruhi penyusunan laporan keuangan.

Kualitas Laporan Keuangan Pemerintah Daerah penting karena salah satu bentuk tata kelola pemerintahan yang baik. Laporan keuangan yang berkualitas dapat memberikan manfaat dalam upaya mengambil kebijakan suatu pemerintahan di masa yang akan datang. Apabila laporan keuangan sudah dapat memberikan manfaat dalam membuat keputusan maka akan mendorong percepatan pembangunan dan pengentasan kemiskinan. Maka kemampuan pengelola keuangan dalam pemerintahan harus memiliki kemampuan dan kreteria yang memadai untuk menghasilkan laporan keuangan yang berkualitas. Penelitian ini menguji pengaruh empat faktor di atas terhadap kualitas laporan keuangan.

\section{Tujuan Penelitian}

1. Untuk mengetahui pengaruh Standar Akuntansi Pemerintah, Sistem Pengendalian Intern, Sistem Informasi Akuntansi, Kompetensi sumberdaya manusia berpengaruh secara bersama-sama terhadap Kualitas Laporan Keuangan OPD di Kabupaten Labuhanbatu

2. Untuk mengetahui pengaruh Standar Akuntansi Pemerintah terhadap Kualitas Laporan Keuangan OPD di Kabupaten Labuhanbatu

3. Untuk mengetahui pengaruh Sistem pengendalian Intern terhadap Kualitas Laporan Keuangan OPD di Kabupaten Labuhanbatu

4. Untuk mengetahui pengaruh Sistem Informasi Akuntansi Keuangan Daerah terhadap Kualitas Laporan Keuangan OPD di Kabupaten Labuhanbatu

5. Untuk mengetahui pengaruh Kompetensi Sumber Daya Manusia terhadap Kualitas Laporan Keuangan OPD di Kabupaten Labuhanbatu 


\section{Teori Keagenan}

Teori keagenan menyatakan bahwa perusahaan yang memisahkan fungsi pengelolaan dan kepemilikan akan rentan terhadap konflik keagenan (Jensen and Mackling, 1976). Pada model keagenan dirancang sebuah sistem yang melibatkan kedua belah pihak yaitu manajemen dan pemilik. Selanjutnya, manajemen dan pemilik melakukan kesepakatan (contract) kerja untuk mencapai manfaat (utility) yang diharapkan. Lambert (2001) menyatakan bahwa dalam kesepakatan tersebut diharapkan dapat memaksimumkan utilitas pemilik (principal), dan dapat memuaskan serta menjamin manajemen (agent) untuk menerima reward. Manfaat yang diterima oleh kedua pihak didasarkan pada kinerja perusahaan. Pada umumnya, kinerja perusahaan diukur dari profitabilitas (Penman, 2003). Besarnya profitabilitas, selanjutnya diinformasikan oleh manajemen kepada pihak pemilik melalui penyajian laporan keuangan. Jensen dan Meckling (1976) menjelaskan bahwa terdapat perbedaan kepentingan antara prinsipal dan agent, sehingga agent tidak selamanya mengikuti keinginan prinsipal. Hubungan keagenan tersebut juga terjadi di pemerintahan antara rakyat sebagai agen dan pemerintah sebagai prinsipal. Pemerintah dapat melakukan kebijakan yang hanya mementingkan pemerintah dan penguasa dan mengorban kan kepentingan dan kesejahteraan rakyat. Untuk mengurangi konflik maka diperlukan monitoring oleh prinsipal atas apa yang dilakukan oleh agen. Laporan keuangan adalah salah satu bentuk alat monitoring untuk mengurangi agency cost.

Menurut Lane (2000) teori keagenan dapat diterapkan dalam organisasi publik. Ia menyatakan bahwa negara demokrasi modern didasarkan pada serangkaian hubungan prinsipal - agen. Sesuai dengan yang dikemukakan oleh Moe (1984) yang menjelaskan konsep ekonomika organisasi sektor publik dengan menggunakan teori keagenan. Bergman \& Lane (1990) menyatakan bahwa kerangka hubungan prinsipal agen merupakan suatu pendekatan yang sangat penting untuk menganalisis komitmenkomitmen kebijakan publik. Pembuatan dan penerapan kebijakan publik berkaitan dengan masalahmasalah kontraktual, yakni informasi yang tidak simetris (asymmetric information), moral hazard, dan adverse selection.

\subsection{Kualitas Laporan Keuangan Pemerintah Daerah}

Laporan keuangan adalah produk akhir dari proses akuntansi yang telah dilakukan. Dalam PP No.71 Tahun 2010, PSAP No. 1 Paragraf 9 bahwa: "Laporan keuangan merupakan laporan yang terstrukur mengenai posisi keuangan dan transaksi-transaksi yang dilakukan oleh suatu entitas pelaporan". Sedangkan menurut PP No. 8 Tahun 2006, Pasal 1 ayat 1 menyatakan bahwa: "Laporan keuangan adalah bentuk pertanggungjawaban pengelolaan negara/daerah selama satu periode".

Laporan keuangan pemerintah daerah merupakan gabungan dari laporan keuangan SKPD yang ada dalam pemerintah daerah itu sesuai Kerangka Konseptual PP No. 71 Tahun 2010 Paragraf 24 disusun untuk menyediakan informasi yang relevan mengenai posisi keuangan dan seluruh transaksi yang dilakukan entitas laporan selama satu periode pelaporan. Laporan keuangan SKPD adalah suatu hasil dari proses pengidentifikasian, pengukuran, pencatatan, dari hasil transaksi ekonomi (keuangan) dari entitas akuntansi yang ada dalam suatu pemerintah daerah yang dijadikan sebagai informasi dalam rangka pertanggungjawaban pengelolaan keuangan entitas akuntansi dan pengambilan keputusan ekonomi oleh pihak-pihak yang memerlukan. (Erlina dan Rambe: 2018).

\subsection{Standar Akuntansi Pemerintahan}

Berdasarkan Peraturan Pemerintah Republik Indonesia No 71 Tahun 2010, Standar Akuntansi Pemerintahan, yang selanjutnya disebut SAP adalah prinsip- pinsip akuntansi yang diterapkan dalam menyusun dan menyajikan laporan keuangan pemerintah. Definisi Standar Akuntansi Pemerintahan menurut Indra Bastian (2010:137), yaitu: "Standar Akuntansi Pemerintahan, yang selanjutnya disebut SAP adalah prinsip-prinsip akuntansi yang diterapkan dalam menyusun dan menyajikan laporan keuangan pemerintah. Dengan demikian SAP merupakan persyaratan yang mempunyai kekuatan hukum dalam upaya meningkatkan kualitas laporan keuangan pemerintah di Indonesia."

PenerapanStandar Akuntansi Pemerintahan ini memerlukan pemahaman yang baik dari setiap aparatur yang menyusun dan menyajikan laporan keuangan baik di Pemerintah Pusat maupun Pemerintahan Daerah beserta instansi-instansinya. Setiap kebijakan yang dibuat oleh pemerintah wajib 
dilaksanakan, akan tetapi dalam penerapan tersebut perlu dipahami beberapa dasar pemikiran yang penting yang diharapkan dapat membantu penerapan Standar Akuntansi Pemerintahan. Pemikiran tersebut adalah mengenai basis akuntansi yang dianut dan hubungan antara sistem dan standar. Selanjutnya diikuti proses penyusunan laporan keuangan menurut Standar Akuntansi Pemerintahan yang dihubungkan dengan kondisi masing-masing entitas. Penerapan standar Akuntansi Pemerintahan yang sesuai dalam pemenuhan kewajiban pelaporan pertanggungjawaban keuangan daerah merupakan penentu atas kualitas laporan keuangan yang dihasilkan. Standar Akuntansi Pemerintahan merupakan salah satu aspek penting yang diperlukan untuk meningkatkan kualitas tata kelola keuangan Negara dan pelaporan keuangan pemerintahan (Mahmudi, 2011).

\subsection{Sistem Informasi Akuntansi}

Sistem informasi akuntansi adalah seluruh komponen yang terkait di susun bersama-sama untuk mengumpulkan informasi, data mentah atau data biasa dan mengubah mereka menjadi data keuangan untuk tujuan pelaporan mereka dalam pengambilan keputusan (Rustami dan moghadam, 2010). Konsep sistem akuntansi pemerintah daerah sejalan dengan konsep sistem akuntansi pada umumnya dan sistem akuntansi keuangan dalam SAP. hal ini dibuktikan dalam pasal 1 ayat 11 peraturan pemerintah nomor 71 tahun 2010 tentang SAP yang menyebutkan bahwa sistem akuntansi pemerintah adalah rangkaian sistematik dari prosedur, penyelenggara, peralatan dan elemen lain untuk mewujudkan fungsi akuntansi sejak analisis transaksi sampai dengan pelaporan keuangan di lingkungan organisasi pemerintahan. oleh karena itu, sistem akuntansi pemerintahan daerah adalah rangkaian sistematik dari prosedur penyelenggaraan peralatan dan elemen lain untuk mewujudkan fungsi akuntansi analisis transaksi sampai dengan laporan keuangan di lingkungan organisasi pemerintah daerah.

Peraturan Pemerintah Republik Indonesia Nomor 56 tahun 2005 tentang Sistem Informasi Keuangan Daerah (SIKD) menyebutkan bahwa Sistem Informasi Keuangan Daerah adalah suatu sistem yang mendokumentasikan, mengadministrasikan, serta mengolah data pengelolaan keuangan daerah dan data terkait lainnya menjadi informasi yang disajikan kepada masyarakat dan sebagai bahan pengambilan keputusan dalam rangka perencanaan, pelaksanaan, dan pelaporan pertanggungjawaban pemerintah daerah.

\subsection{Sistem Pengendalian Intern}

Sistem pengendalian intern merupakan suatu perencanaan yang meliputi struktur organisasi dan semua metode dan alat-alat yang dikoordinasikan yang digunakan di dalam perusahaan dengan tujuan untuk menjaga keamanan harta milik perusahaan, memeriksa ketelitian dan kebenaran data akuntansi, mendorong efisiensi, dan membantu mendorong dipatuhinya kebijakan manajemen yang telah ditetapkan (Raharjo, 2013). Berdasarkan Peraturan Pemerintah RI nomor 60 tahun 2008 tentang sistem pengendalian intern, Sistem Pengendalian Intern adalah proses yang integral pada tindakan dan kegiatan yang dilakukan secara terus menerus oleh pimpinan dan seluruh pegawai untuk memberikan keyakinan memadai atas tercapainya tujuan organisasi melalui kegiatan yang efektif dan efisien, keandalan pelaporan keuangan, pengamanan aset negara, dan ketaatan terhadap peraturan perundang- undangan. Sistem Pengendalian Intern Pemerintah, yang selanjutnya disingkat SPIP, adalah Sistem Pengendalian Intern yang diselenggarakan secara menyeluruh di lingkungan pemerintah pusat dan pemerintah daerah.

\subsection{Kompetensi Sumber Daya Manusia}

Kompetensi diartikan sebagai kecakapan, keterampilan, dan kemampuan. Kompetensi juga merupakan pengetahuan, keterampilan dan kemampuan yang berhubungan dengan pekerjaan. Sumber Daya Manusia merupakan modal dan kekayaan yang terpenting dari setiap kegiatan manusia. Manusia sebagai unsur terpenting mutlak dianalisis dan dikembangkan dengan cara tersebut (Fathoni, 2006:8). Waktu,tenaga dan kemampuanya benar-benar dapat dimanfaatkan secara optimal bagi kepentingan organisasi, maupun bagi kepentingan individu. Kompetensi merupakan dasar seseorang untuk mencapai kinerja tinggi dalam menyelesaikan kinerjanya. Sumber daya manusia yang tidak memiliki kompetensi tidak akan dapat menyelesaikan pekerjaanya secara efisien, efektif, dan ekonomis. Dalam hal ini pekerjaan yang dihasilkan tidak akan tepat waktu dan terdapat pemborosan waktu serta tenaga. Dengan adanya kompetensi sumber daya manusia maka waktu pembuatan laporan keuangan akan dapat 
dihemat. Hal ini karena sumber daya manusia tersebut telah memiliki pengetahuan dan pemahaman mengenal hal-hal yang harus dikerjakan, sehingga laporan keuangan yang disusun dapat diselesaikan dan disajikan tepat pada waktunya.

\section{Hipotesis}

Hipotesis dalam penelitian dinyatakan sebagai berikut

H1 : Standar Akuntansi Pemerintah, Sistem Informasi Akuntansi, Sistem Pengendalian Intern, Kompetensi Sumber daya Manusia secara simultan berpengaruh terhadap kualitas Laporan Keuangan OPD di Permerintahan Kabupaten Labuhanbatu.

H2 : Standar Akuntansi Pemerintah berpengaruh terhadap kualitas Laporan Keuangan OPD di Permerintahan Kabupaten Labuhanbatu

H3 : Sistem Informasi Akuntansi berpengaruh terhadap kualitas Laporan Keuangan OPD di Permerintahan Kabupaten Labuhanbatu

H4 : Sistem Pengendalian Intern berpengaruh terhadap kualitas Laporan Keuangan OPD di Permerintahan Kabupaten Labuhanbatu

H5: Kompetensi Sumber daya Manusia terhadap kualitas Laporan Keuangan OPD di Permerintahan Kabupaten Labuhanbatu.

\section{Metode Penelitian}

Penelitian ini dilakukan di wilayah pemerintahan daerah Kabupaten Labuhanbatu yang merupakan salah satu kabupaten yang terletak di Provinsi Sumatera Utara. Subjek yang menjadi responden penelitian ini adalah kepala bagian keuangan dan bendahara pada seluruh OPD di Kabupaten Labuhanbatu. Pengambilan data dengan cara memberikan kuisioner kepada responden penelitian ini. Selanjutnya data yang diperoleh dianalisis menggunakan regresi linear berganda dengan bantuan program SPSS, dengan terlebih dahulu melakukan uji asumsi klasik sebagai syarat untuk melakukan uji regresi berganda. Model persamaan regresi dalam penelitian ini adalah

$$
\mathrm{Y}=\mathrm{a}+\mathrm{b} 1 \mathrm{X} 1+\mathrm{b} 2 \mathrm{X}_{2}+\mathrm{b} 3 \mathrm{X} 3+\mathrm{b} 4 \mathrm{X} 4+\mathrm{e}
$$

\section{Keterangan}

Y $\quad=$ Kualitas Laporan Keuangan

a $\quad=$ Konstanta

$\mathrm{b} \quad=$ Koefisien Regresi

$\mathrm{X} 1=$ Standar Akuntansi Pemerintah

$\mathrm{X} 2=$ Sistem Informasi Akuntansi

$\mathrm{X} 3=$ Sistem Pengendalian Intern

X4 = Kompetensi Sumber Daya Manusia

$\mathrm{e} \quad=$ Variabel pengganggu

\section{Hasil dan Pembahasan}

Sebagaimana yang telah dijelaskan sebelumnya bahwa sebelum dilakukan uji hipotesis, terlebih dahulu dilakukan uji asumsi klasik yang terdiri dari uji normalitas, uji heteroskedastisitas, uji linearitas, dan uji multikolinearitas sebagai syarat untuk uji regresi. Hasil pengujian data menunjukkan bahwa data dalam penelitian ini bebas dari asumsi klasik, yang berarti dapat dilakukan uji regresi untuk menguji hipotesis penelitian ini.

Hipotesis pertama diuji dengan menggunakan uji F. Hasil uji F dapat dilihat pada tabel berikut.

Tabel 1 : Hasil Uji F

\begin{tabular}{ll|r|r|r|r|r} 
& Sum of Squares & df & Mean Square & F & Sig. \\
\hline 1 & 666.790 & 4 & 166.697 & 38.192 & $.000^{\mathrm{b}}$ \\
\hline & Regression & 240.060 & 55 & 4.365 & & \\
\hline Residual & 906.850 & 59 & & & \\
\hline Total & & & & \\
\hline
\end{tabular}


Tabel di atas menunjukan bahwa nilai sig 0.000 dimana tingkat signifikan di bawah 0,05 . Hal ini menunjukkan bahwa variable-variabel independen yaitu standar akuntansi pemerintah, sistem informasi akuntansi, system pengendalian intern, kompetensi sumber daya manusia secara simultan berpengaruh terhadap variabel dependen yaitu kualitas laporan keuangan. Ini berarti H1 diterima.

Hasil pengujian hipotesis berikutnya menggunakan uji t dapat dilihat pada tabel berikut.

Tabel 2 : Hasil uji t

\begin{tabular}{|c|c|c|c|c|c|c|}
\hline \multirow[b]{2}{*}{ Mode } & \multicolumn{3}{|c|}{ Unstandardized Coefficients } & \multirow{2}{*}{$\begin{array}{c}\text { Standardized } \\
\text { Coefficients } \\
\text { Beta } \\
\end{array}$} & \multirow[b]{2}{*}{$\mathrm{t}$} & \multirow[b]{2}{*}{ Sig. } \\
\hline & & B & Std. Error & & & \\
\hline \multirow[t]{5}{*}{1} & (Constant) & -7.211 & 3.998 & & -1.803 & .077 \\
\hline & $\mathrm{X} 1$ & .803 & .183 & .776 & 4.378 & .000 \\
\hline & $\mathrm{X} 2$ & .142 & .147 & .204 & 3.969 & .000 \\
\hline & $\mathrm{X3}$ & -.159 & .150 & -.139 & -1.057 & .295 \\
\hline & $\mathrm{X} 4$ & -.134 & .187 & -.072 & -.718 & .476 \\
\hline
\end{tabular}

Berdasarkan pengujian hipotesis kedua, ditemukan hasil bahwa standar akuntansi pemerintah berpengaruh terhadap kualitas laporan keuangan OPD (Organisasi Pemerintah Daerah) di pemerintahan Kabupaten Labuhan Batu. Nilai signifikansi variabel standar akuntansi pemerintah sebesar 0,000. Maka tinggi atau rendahnya tingkat kepatuhan pemakai Standar Akuntansi Pemerintah dalam penyusunan laporan keuangan dapat menetukan kualitas Laporan Keuangan. Hasil Penelitian ini sejalan dengan penelitian Putriasri dan Abdullah (2017) yang menyatakan bahwa standar akuntansi pemerintah berpengaruh terhadap kualitas laporan keungan. Standar Akuntansi Pemerintahan merupakan pedoman penyajian laporan keuangan. Pemerintah daerah mempunyai kewajiban untuk menyajikan laporan keuangan sebagai bentuk tanggung jawabnya terhadap pengelolaan keuangan.

Penelitian ini juga didukung oleh Wayan dan Gusti (2017) yang menyatakan bahwa penerapan standar akuntansi pemerintahan berpengaruh positif pada kualitas laporan keuangan. Penerapan standar akuntansi pemerintahan secara efektif, memudahkan pemerintah dalam penyusunan laporan keuangan karena standar akuntansi pemerintahan merupakan pedoman didalam penyusunan laporan keuangan untuk menghasilkan laporan keuangan yang berkualitas. Efektivitas penerapan standar akuntansi pemerintahan berkaitan dengan Teori Keagenan. Teori ini menjelaskan bahwa pemerintah daerah selaku agent harus memenuhi kebutuhan masyarakat selaku principal yang diwaliki oleh DPR dalam hal menghasilkan laporan keuangan yang berkualitas agar memudahkan principal dalam mengambil keputusan.

Berdasarkan pengujian hipotesis ketiga, ditemukan hasil bahwa system informasi akuntansi berpengaruh terhadap kualitas laporan keuangan OPD (Organisasi Pemerintah Daerah) di pemerintahan Kabupaten Labuhan Batu. Nilai signifikansi variabel system informasi akuntansi sebesar 0,000. Maka tinggi atau rendahnya tingkat kepatuhan penggunaan sistem informasi akuntansi dapat menentukan kualitas laporan keuangan.

Hasil ini didukung Irzal dan Suparno (2017) yang menyatakan bahwa sistem informasi akuntansi berpengaruh terhadap kualitas laporan keuangan SKPD Kota Banda Aceh. Laporan keuangan dihasilkan dari suatu proses yang didasarkan pada input yang baik, proses yang baik dan output yang baik. Suatu informasi yang disajikan membutuhkan sebuah sistem dalam penyusunannya. Penerapan sistem informasi akuntansi dalam menghasilkan laporan keuangan yang berkualitas berhubungan dengan teori keagenan. Teori ini menjelaskan bahwa pembuatan dan penerapan kebijakan public berkaitan dengan masalah-masalah kontraktual, yakni informasi yang simetris. Sistem informasi akuntansi adalah rangkaian prosedur yang dilakukan mulai dari mengumpulkan, mencatat, menggolongkan, dan meringkas serta melaporkan transaksi.

Berdasarkan pengujian hipotesis keempat, ditemukan hasil bahwa sistem pengendalian intern tidak berpengaruh terhadap kualiatas laporan keuangan. Nilai signifikansi variabel sistem pengendalian intern sebesar 0,295 . Hal ini terjadi karena rendahnya tingkat pengawasan pimpinan pada penyusunan 
laporan keuangan. Hal ini dapat dilihat dari beberapa jawaban responden yang menjawab 3 (Netral) dan 1 (Sangat Tidak Setuju). Dimana berdasarakan jawaban tersebut dapat di nyatakan sebagian pimpinan OPD tidak melakukan pemeriksaan terhadap laporan keuangan selaku pengendali internal.

Hasil penelitian ini didukung oleh Dini dan Frans (2016), mengatakan Sistem pengendalian intern tidak berpengaruh terhadap kualitas laporan keuangan, karena sistem pengendalian intern yang baik apabila tidak diterapkan secara efektif akan menimbulkan banyak ketidaksesuaian antara proses yang berjalan dengan peraturan yang berlaku, sehingga kualitas laporan keuangan yang dihasilkan tidak semakin baik. Sementara hasil penelitian Wayan dan Gusti (2017) bahwa sistem pengendalian intern berpengaruh positif pada kualitas laporan keuangan. Penerapan sistem pengendalian intern dalam menghasilkan laporan keuangan yang berkualitas berkaitan dengan Teori Keagenan. Teori ini menjelaskan bahwa pemerintah daerah selaku agent harus memenuhi kebutuhan masyarakat selaku principal yang diwaliki oleh DPR dalam hal menghasilkan laporan keuangan yang berkualitas agar memudahkan principal dalam mengambil keputusan.

Berdasarkan pengujian hipotesis kelima, ditemukan hasil bahwa kompetensi sumber daya manusia tidak berpengaruh terhadap kualiatas laporan keuangan. Nilai signifikansi variabel kompetensi sumber daya manusia sebesar 0,476. Artinya hipotesis keempat dalam penelitian ini ditolak. Hal ini dapat dilihat dari jawaban responden yang menjawab point 3 (Netral). Berdasarkan jawaban tersebut kompetennya sumber daya manusia dalam penyusunan laporan keuangan tidak dilihat dari seberapa besar pengetahuan, keahlian, dan perilaku nya dalam penyusunan laporan keuangan.

Hasil penelitian ini berbeda dengan Kuasa, dkk (2016) yang menyatakan bahwa kompetensi berpengaruh terhadap kualitas laporan keuangan SKPD dilingkungan pemerintah Kabupaten Simeulue. Semakin kompeten sumber daya manusia yang dimiliki maka semakin berkualitas laporan keuangan yang dihasilkan. Hubungan antara kompetensi sumber daya manusia dan kualitas laporan keuangan dapat dijelaskan oleh Teori Keagenan. Teori ini menjelaskan bahwa pemerintah daerah selaku agent harus memenuhi kebutuhan masyarakat selaku principal yang diwaliki oleh DPR dalam hal menghasilkan laporan keuangan yang berkualitas agar memudahkan principal dalam mengambil keputusan. Sumber daya yang kompeten akan memudahkan pemerintah daerah dalam penerapan standar akuntansi pemerintahan sehingga mampu menghasilkan laporan keuangan yang berkualitas.

\section{Kesimpulan dan Saran}

Berdasarkan analisis dan pembahasan mengenai pengaruh standar akuntansi pemerintah, sistem informasi akuntansi, sistem pengendalian intern, dan kompetensi sumber daya manusia terhadap kualitas laporan keuangan OPD di Kabupaten Labuhanbatu, maka dapat ditarik kesimpulan sebagai berikut:

1. secara bersamaan variabel standar akuntansi pemerintah, sistem informasi akuntansi, sistem pengendalian intern, dan kompetensi sumber daya manusia memiliki pengaruh terhadap kualitas laporan keuangan yaitu memiliki pengaruh sebesar 37,3\% dan selebihnya dipengaruhi oleh variabel lain di luar keempat variabel diatas.

2. Standar akuntansi pemerintah memiliki pengaruh negative terhadap kualitas laporan keuangan.

3. Sistem informasi akuntansi memiliki pengaruh negative terhadap kualitas laporan keuangan.

4. Sistem pengendalian intern tidak memiliki pengaruh terhadap kualitas laporan keuangan

5. Kompetensi sumber daya manusia tidak memiliki pengaruh terhadap kualitas laporan keuangan

Terdapat beberapa keterbatasan yang kemungkinan dapat berpengaruh pada hasil penelitian yaitu penelitian dilakukan dengan metode survey yaitu pembagian kuesioner sehingga hasil yang didapat dari responden akan mempengaruhi hasil penelitian, karena hasil yang diberikan tidak sesuai dengan keadaan yang sebenarnya terjadi. Dalam penelitian ini juga ada beberapa responden yang kurang paham dengan pertanyaan dan kurang mengetahui kondisi yang terjadi dalam pengelolaan keuangan daerah. Penelitian ini hanya menggunakan empat variabel independen yaitu standar akuntansi pemerintah, sistem informasi akuntansi, sistem pengendalian intern dan kompetensi sumber daya manusia.

Berdasarkan kesimpulan keterbatasan diatas, maka berikut ini beberapa saran yang dapat dipertimbangkan:

1. Bagi peneliti lain hasil penelitian menunjukkan Nilai R Square yang rendah disarankan untuk memperluas factor lain yang dapat meningkatkan kualitas laporan keuangan. Misalnya budaya 
organisasi, motivasi kerja, komitmen organisasi, dan pemanfaatan teknologi informasi, atau variabel lainnya. Penelitian selanjutnya juga dapat mengembangkan penelitian ini dengan menggunakan metode penelitian yang berbeda agar dapat dicapai hasil yang lebih baik.

2. Bagi pemerintah hasil penelitian ini menyarankan pimpinan bagian dalam OPD Labuhanbatu agar memperhatikan dukungan pimpinan dan peraturan yang ada terhadap penyusunan laporan keuangan

\section{Daftar Pustaka}

Aditya, Oka Reza dan Welly Surjono. 2017. Pengaruh Sistem Pengendalian Intern Terhadap Kualitas Laporan Keuangan. Sikap, Vol 2 (No.1), 2017, hal 49-62.

Alifah, Syayyidah dan Wahidahwati, Bambang Waluyo. 2014. Faktor-Faktor Yang Mempengaruhi Nilai Informasi Pelaporan Keuangan Badan Layanan Umum (Studi Pada PK BLU Universitas Negeri Surabaya). Jurnal Ilmu Riset dan Akuntansi. Volume 3. Nomor 12.

Andvig, Jens Chr., Odd-Helge Fjeldstad, Inge Amundsen, Tone Sissener \& Tina Søreide. 2001. Corruption A Review of Contemporary Research. Chr. Michelsen Institute Development Studies and Human Rights Report R 2001: 7. Web: http//www.cmi.no

Anggraeni, Dian Tri dan Akhmad Riduwan. 2014. Faktor-Faktor Yang Mempengaruhi Keterandalan Pelaporan Keuangan Pemerintah Daerah (Studi Pada SKPD di Kabupaten Sidoarjo). Jurnal Ilmu dan Riset Akuntansi.Volume 3. Nomor 3.

Arfianti, D. 2011. Analisis faktor-faktor yang mempengaruhi nilai informasi pelaporan keuangan Pemerintah Daerah(Studi pada satuan kerja Perangkat Daerah di Kabupaten Batan. Tesis tidak diterbitkan. Univeristas Diponegoro Semarang.

Aruan N. (2003)."Kompetensi Aparatur Pemerintah Daerah Studi Empiris di Jawa Timur". Jawa Timur: Badan Penelitian dan Pengembangan Propinsi Jawa Timur

Bastian, Indra. 2010. Akuntansi Sektor Publik Edisi Ketiga. Jakarta: Erlangga

Erlina,dkk. 2018. Akuntansi Keuangan Daerah Berbasis Akrual. Jakarta: Salemba empat

Ghozali, imam. 2016. Aplikasi Analisis Multivariete dengan IBM SPSS 23, edisi 8. Semarang. Badan penelitian Universitas Diponegoro

Herlinda. 2016. Analisis Faktor-faktor yang Mempengaruhi Kualitas Informasi Laporan Keuangan Pemerintah Daerah (Studi Empiris pada Pemerintah Kabupaten/Kota di Provinsi Riau). Volume. 11. Nomor 2. $127-144$

Ikhtisar Hasil Pemeriksaan Semester (IHPS) I Tahun 2015, Buku II PemeriksaanLaporan Keuangan. Diunduh Desember 2015.

Ikhtisar Hasil Pemeriksaan Semester (IHPS) I Tahun 2016, Buku II PemeriksaanLaporan Keuangan. Diunduh Desember 2016

Ikhtisar Hasil Pemeriksaan Semester (IHPS) I Tahun 2019, Buku II PemeriksaanLaporan Keuangan. Diunduh Desember 2019.

Jensen, M. and W. Meckling. 1976. "Theory of the Firm: Managerial Behavior, Agency Cost and Ownership Structure.” Journal of Financial Economics, (3): 305 - 360.

Karsana, Wayan dan I Gusti Ngurah Agung Suaryana. 2017.Pengaruh Efektivitas Penerapan Sap, 
Kompetensi Sdm, Dan Spi Pada Kualitas Laporan Keuangan Pemerintah Kabupaten Bangli. EJurnal Akuntansi Universitas Udayana Vol.21.1. Oktober (2017): 643-670. Issn: 2302-8556

Keputusan Kepala Badan Kepegawaian Negara No 46A Tahun 2007. Pedoman Penyusunan Standar Kompetensi Jabatan Struktural Pegawai Negeri Sipil. Diakses pada 1 November 2015, dari http:/mahsanafifiles.wordpress.com

Peraturan Pemerintah (PP) Nomor 8 Tahun 2006 Tentang Pelaporan Keuangan dan Kinerja Instansi Pemerintah

Peraturan Pemerintah Dalam Negeri Nomor 4 Tahun 2008 Tentang Pedoman Pelaksanaan Reviuw Atas Laporan Keuangan Pemerintah Daerah

Peraturan Pemerintah Republik Indonesia Nomor 60 Tahun 2008 Tentang Sistem pengendalian Internal Peraturan Pemerintah (PP) Nomor 71 Tahun 2010 Tentang Standar Akuntansi Pemerintahan Indonesia Sekaran, Uma dan Roger. 2017. Metode Penelitian untuk Bisnis. Jakarta: Salemba Empat

Septarini, Dina Fitri dan Frans Papilaya. 2016. Interaksi Komitmen Organisasi Terhadap Faktor-Faktor Yang Memengaruhi Kualitas Laporan Keuangan Pemerintah Daerah. Jurnal Ilmu Ekonomi \& Sosial, Vol.Vii, No. 2, Oktober 2016; 100-116 P-Issn: 2085-8779 E-Issn: 2354-7723 